\title{
Reconceptualizing STEM Education in China as Praxis: A Curriculum Turn
}

\author{
Ying Ma
}

Citation: Ma, Y. Reconceptualizing STEM Education in China as Praxis: A Curriculum Turn. Sustainability 2021, 13, 4961. https://doi.org/10.3390/ su13094961

Academic Editors: Marc A. Rosen and Maija Aksela

Received: 14 March 2021

Accepted: 24 April 2021

Published: 28 April 2021

Publisher's Note: MDPI stays neutral with regard to jurisdictional claims in published maps and institutional affiliations.

Copyright: (C) 2021 by the author. Licensee MDPI, Basel, Switzerland. This article is an open access article distributed under the terms and conditions of the Creative Commons Attribution (CC BY) license (https:// creativecommons.org/licenses/by/ $4.0 /)$.
Department of Curriculum Studies, Faculty of Education, University of British Columbia, Vancouver, BC V6T 1Z4, Canada; anita.maying@gmail.com or ying.ma@ubc.ca

\begin{abstract}
STEM education has drawn considerable international attention in recent decades. Current practices of STEM Education in China have shown that STEM is understood primarily as a policydriven and economic problem. This paper challenges the reduced technical frameworks of STEM education and draws on the theoretical framework of the reconceptualization movement in the curriculum field. It aims to shift scientific or social science paradigms with languages of humanity to reapproach STEM education. STEM education is hence reconceptualized as praxis in its lived, ethical and historical dimensions. It would transform STEM education in China from being targeted for economic growth to attending to lived, nuanced and rich STEM experiences, structured by ethics and threaded by history. STEM teachers and teacher educators are advised to understand anew about STEM in their situatedness. STEM could serve as an opportunity to critically reflect on and research each discipline in greater depth with inter-disciplinary lenses. Instead of integrating science, technology, engineering and mathematics seamlessly to form omnipotent toolsets for the 21st-century workforce in China and on the international landscape, a reconceptualization of STEM as praxis could continue to generate more sustainable STEM education.
\end{abstract}

Keywords: STEM education in China; praxis; curriculum reconceptualization

\section{Introduction}

STEM education has been spreading around the globe and the researches around it have been proliferating [1-6] since it originated from the U.S. as a strategic response to the former Soviet Union's successful launch of a satellite into outer space in the 1950s. In the last two decades, STEM education has gained unprecedented attention worldwide. The second decade of the 21st century has witnessed governments and industry globally intensify their focus on the role of STEM as a vehicle for future economic prosperity. In China, STEM education has been elevated to a strategic national movement with series of educational policies and implementations [7]. The boom of STEM education in China has been driven by the government's favorable policies and determination to boost the economy through technological means. This official discourse sets the tone for STEM education enterprise. Within this discourse, schools and universities are considered as venues to promote students' performance in STEM and, hence, help build a qualified and competent workforce for the future, which is often largely conceived as a policy issue geared towards economic ends. Besides the economic and policy-driven traits of STEM education in China, STEM also anchors on metacognitive development of students, aiming at reflection upon one's own cognitive process and "knowledge about strategies that can be applied to the solution of different tasks, and skills for monitoring and regulating one's cognitive activities" [8] (p. 167). Metacognitive approaches to STEM draw heavily on the language of modernity, with psychological underpinnings such as "monitoring", "regulating" and "applying" risking the narrowing of interpretative scopes of STEM education in China.

In school settings, STEM teachers are expected to implement and apply policies and take control of the cognitive learning processes of their students. Developmental stages are often equalized with "cultivating students' problem-solving ability ... in line with 
the training requirements for innovative talents" [9] (p. 6). The linear approaches to STEM [9] coincide with Ralph Tyler's basic principles of curriculum from the 1970s [10]. Unfortunately, there are insufficient discussions in STEM education from lived, ethical, and historical perspectives. These humanitarian discourses and perspectives, which come to thrive in the reconceptualization movement [11], could complicatedly help us live STEM education anew. This paper intends to complicate discourses about STEM education in the context of China and reconceptualize STEM education as praxis. It firstly addresses how STEM education is implemented in the Chinese context. Secondly, it appropriates the understanding curriculum paradigm [11] to reconceptualize STEM education as praxis through humanistic traditions. The lived, ethical and historical dimensions of STEM education are discussed in the respective sections. Finally, it situates China's STEM education in a global landscape and comments on the implications of reconceptualization on STEM educators and education in China and beyond. This attempt will contribute to the sustainable evolution of STEM education: STEM rejuvenates and generates its meanings in the rich soil of praxis rather than being advanced by the boosters of external policies. Reconceptualizing STEM education in China as praxis helps sustain its rigor and vitality by being well situated in experiential, ethical and historical grounds.

\section{China's STEM Education Policies and Practices}

In 2016, the Ministry of Education in China issued the "The 13th Fifth Year Plan for Education in the Information Age", and officially mentioned promoting interdisciplinary STEM education, together with creating a Group Innovation Space [12]. The next year, in the national curriculum for China's elementary and secondary schools, the subjects of technology and engineering were added for the first time, integrating the interdisciplinary STEM educational goals to the curriculum standards for subjects including physics, chemistry, biology, geography, information technology, as well as general technology [13].

China's STEM education environment plays a pivotal role in influencing the successful transitioning from a manufacturing-based economy to an innovation-driven, knowledgebased economy [14]. The newly founded "STEM Education Research Center in China" has, since 2017, built different collaborative centers in different provinces and initiated "China's STEM Education White Paper" [1] and "STEM Teachers Competency Level Standards" [15], both of which are targeted at the standardization of STEM education and the professionalization of STEM educators. In 2018, the Ministry of China, together with six other departments, collectively issued "The Plan for Excellent Students Cultivation" [16], which emphasized interdisciplinary and integrational approaches as the primary venues to cultivate innovative elites. The plan suggested that there was a need to build a curriculum system that provided favorable conditions for academically excellent students to participate in interdisciplinary practices. According to the plan, it aimed to help students balance the depth and breadth of knowledge and construct a pyramid knowledge structure. Collaboration between schools and research institutions is encouraged: students are given opportunities to get involved in national science by joining the cutting-edge practices of scientific and technological innovation. In the same year, the launching ceremony for the 2029 Action Plan for China's STEM Education was held in Beijing, China. This plan "aims at allowing as many students to benefit from STEM education as possible and equips all students with scientific thinking and the ability to innovate" [7].

The very first STEM Education Curriculum Outline in Jiangsu Province, China, sticks to the economic-drive, project and outcome-oriented STEM education, emphasizing integrative, structural and localized designs [6]. In the Outline, the goals of STEM Education in China are described and summarized in five dimensions, including knowledge integration, systematic design and innovation, experiment and expression, cultural experience and recognitions, as well as scientific attitude and responsibility.

STEM education in China has been characterized as being technologically intense and innovative. It is determined on national level that technology provides education its structure and content $[16,17]$. STEM education in China is primarily conceived as a policy 
issue consisting of designing and implementation problems, whose primary goal is to promote economic growth and the competency skills of the future workforce. In response to the encouraging policies by the government, schools in both public and private sectors around the country began to carry out STEM education programs. To effectively implement STEM curricula, full-time teachers who specialized in STEM education or relevant subjects are in urgent demand. At present, the problems with STEM advancement are framed around a lack of qualified STEM teachers, and a training system yet to be established; certification of new STEM teachers and inadequate admittance systems [7].

Developing core competencies, promoting communicative, collaborative, critical and innovative "21st-century skillset", as well as contributing to the innovative country with advanced science and technology, define the ultimate goals of China's STEM education [6]. On both policy and practice levels, China's STEM Education has been primarily focused on its implementation and development within technological, scientific discourses. STEM education is conceived and implemented solely as a developmental strategy in schools tainted with scientific innovation and interdisciplinary assumptions. Joseph Schwab directs our attention to different dimensions of scientific practices in his famous article "what do scientists do?". Besides the "hole in science and instrument mastered", Schwab points out the dimension of virtuosity per se as the starting point of enquiry [18] (p. 22). The characters and subjectivities of human beings play significant roles in scientific enquiries: who they are and what they do and think should not be obscured by quantifiable variables. STEM in China is now heavily correlated with scientific and experimental traditions, which require closer and more nuanced scrutiny in complicated conversations.

\section{STEM Education as Praxis-A Curriculum Turn}

Despite considerable national interest in STEM, few discussions in policymaking and practices have shown much interest in what STEM means in terms of a curriculum concept, derived from the reconceptualization movement in the 1970s. STEM education in China's context often solely demands "practices based on instrumental effectiveness and better assessment" [19] (p. 2). The overall lack of interest in understanding STEM in alternative languages might threaten, over the long-term, to destroy support for its sustainable movement [5].

In research around STEM, inconsistencies are detected in the definition and enactment of STEM, which calls for a deconstruction of the concept to create an alternate and more easily understood grouping of capabilities [20]. The acronym STEM entails different interpretations. STEM is often identified as an umbrella term for the teaching of one or more of its constituent disciplines. Sometimes, STEM education is used as a pseudonym for the umbrella term science education. In some other cases, it refers to interdisciplinary, multidisciplinary, or integrated approaches [21]. Fraser et al. also categorize STEM education on different layers: "occupation or discipline-related technical skills (e.g., coding, design, and construction); socio-emotional skills (e.g., resilience, curiosity, and empathy), advanced cognitive skills (e.g., critical and creative thinking), and foundational literacies needed for everyday life (e.g., numeracy)" [20] (p. 12). Whether a commitment to an individual or separate discipline or an advocate for a more integrated approach, or even if targeted at certain content or skill, the framework for STEM is primarily technical, subset of the cognitive skills [22] and it is constructed largely as an epistemological issue. The technical-oriented and competency-based grouping of STEM education tends to neglect the lived, ethical and historical dimensions of STEM. This paper does not intend to draw on particular notions or groupings of STEM education. On the contrary, it aims to disturb existing technical frameworks and discourses underlying STEM and offer renewed perspectives and languages.

To go beyond the concept of a technological fix and economic enhancer in its situatedness and specificity, STEM education needs to be given a curricular turn [23]. Huebner proposes the necessity of moving beyond scientific and empirical language in the explanation of educational phenomenon [24]. Phelan recommends a curriculum turn to challenge 
the conceptualization of teacher education as an organizational term, and tries to challenge its parochialism, which confines the purpose of teacher education and promise of inquiry [23]. Phelan refers to William Pinar and Dwayne Huebner to reimagine and challenge the parochial tendencies and discourses in teacher education [23]. In a similar light, I attempt to reconceptualize STEM education in China with a curriculum turn, creating a renewed conceptual landscape. The curricular turn refocuses on the experiential ground of STEM education and, hence, allows it to evolve sustainably and creatively rather than being reduced to technical means towards economic ends.

Re-understanding STEM with perspectives from the curriculum reconceptualization movement of the 1970s [24] could deepen, enrich and alternate prevalent discourses and find the new openings for STEM education in China. In contrast with the curriculum development tradition as prescriptive and instrumental, the reconceptualization movement focuses on understanding curricula through having complicated conversations. It is a reconstruction of the curriculum field in the critique of Tyler's curriculum, which emphasizes designing, behavioral changes, assessment and improvement [10]. The reconceptualization movement aimed to understand rather than implement or evaluate the curriculum. As such, we see the movement was open to and embraced various forms of praxis, including but not limited to the historical, the ethical, the autobiographical and the aesthetics.

Originating from Aristotelian languages and initially advanced by Huebner in the curriculum field in the 1970s, praxis involves thought and action, a key concept in curriculum reconceptualization. Ted Aoki interprets that praxis as "action done reflectively, and reflection on what is being done" [25] (p. 120). Praxis resists the temptation to be standardized or assessed because it depends on acting well in each particular circumstance, at a particular place, at a particular time and with a particular person. Re-understanding STEM education in China as praxis is not an innovative concept but a returning journey to ancient wisdom and a reactivation of it in today's context. It reframes STEM education in China, from being largely reconceived as the implementation of policies and development of "how-to" techniques, to reflective actions with multiple dimensions of the phenomenological and hermeneutical, the ethical and the historical, imbued with possibilities to make meanings anew in life. The reconceptualization of STEM as praxis bears potential to fashion more sustainable STEM landscapes characterized by nuanced and messy experiences, structured by ethics and threaded by history.

\subsection{STEM as Lived Experiences}

China's STEM education primarily adopts the scientific paradigm focused on experimental approaches to science problems, emphasizing fundamental knowledge and skills as instruments [3]. Gao observes STEM education in China is "no longer isolated from industrial development. Through cooperation between universities and industries, scientific knowledge has been successfully transferred to productivity and directly contributes to national economic growth" [3] (p.64). Schwab, around six decades ago, critically points out the significance of enriching the scope of scientific enquiry in its embeddedness and vividness. He elaborates, "the scope of an enquiry rarely includes the full richness of its subject matter and what is omitted from its formulations is most vividly seen in the individual case which acts 'contrary to the scientific law' because what is acting is something more complex than the subject-of-enquiry subsumed in the 'law' in question" [18] (p. 11). In critiques of Thorndike's framework of behavioural psychology, Taylor's scientific management and Bobbitt's curriculum analysis and development, Pinar comments: "[they assert] the effectiveness, efficiency, and economy are crucial concepts for the curriculum maker .... The work of the curriculum maker became studying the adult world to determine the major tasks or activities composing it. These tasks would then compromise the curriculum" [24] (p. 97). Pinar cautions us about the limitations of emerging scientism which applies scientific techniques from business and industry to the educational field.

To redeem STEM education in China from being preoccupied with scientism towards the economic ends and, unfortunately, remaining trapped in the discourses of modernity, 
STEM educators need to attend to and dwell in the lived experience in relationships with others, the discussions around which are largely missing from prevalent scientific discourses in China regarding experiments, hypothesis and evidence, principles and rationales [1-7]. Reapproaching STEM as praxis could primarily help recover the messiness and richness of experiences. Praxis "focuses on what is variable, on that which cannot be encapsulated by universal rules, on specific cases" [26] (p. 57). In light of praxis, theories are pulled back to the "rough ground" of experiences, generating renewed actions ready for further reflection [27]. Lived experiences are open to, as I understand, both hermeneutic fusion and confusion: the fusion is not oriented for a harmonic and seamless whole but always leaves room and edges for more confusions which welcome further reflection. Confusion is of particular significance because it generates a poignant space for human wonders and deeper reflections. STEM education reconceived as praxis would leave room for those uncertainties and hesitations, disturbing the fantasy of stable knowledge and demonstrating the "futility of standardization" [23] (p. 216). The subtleties, unstableness and messiness of lived experience generate the creative power for alternatives, creating new possibilities. For STEM education in China, policymakers are advised to get over the naivety and arrogance of applying the instruments of STEM curriculum design to promote prescribed outcomes, often in line with economic and societal needs. These would risk continuing to subsume STEM education to the technological society and instrumental rationality. Instead, STEM educators need to creatively and imaginatively tap on multiple realties of human experience and "reawaken concern for and belief in a humane framework for the kinds of education required in a technological society [28] (xvi).

It is worth quoting Greene directly and at length here: "I could not objectify nor separate my subjectivity from what I was perceiving. I could not separate my feeling, imagining, wondering consciousness from the cognitive work assigned for me to do, nor could I bracket out my biography and my experiences of embeddedness in an untidy, intersubjective world" [29] (p. 115). STEM education is, after all, education by/with/for human beings. Unfortunately, STEM education in China appears to be a vessel towards somewhere afar, an object to be examined and packaged to be delivered. Ted Aoki, a Japanese-Canadian curriculum theorist, also advises that "science must be taught as humanity" [25] (p. 199). Aoki regards it more as a question than a statement. It fundamentally disturbs categories and dissolves the rigid boundaries between science and humanities, calling into question the underlying condition that allows science and the humanities to exist in separate domains. Aimed at more than simple integration, Aoki's question is significant in resisting and disrupting the dichotomizing tendency of science and the humanities. He speaks to the tension between lived curriculum and planned curriculum and hopes to build towards a curricular landscape of multiplicity [25]. Aoki displaces the curriculum as planned primacy with interpreting multiplicity, not as a noun but a verb growing in the middle between curriculum as the lived and as a plan. He proposes to "[dwell] in midst of a multiplicity of curricula, between and among curriculum-as-plan and the lived curricula ... where ... multiplicity grows as lines of movement" [25] (p. 205). These lines of movement are grounded in differences: the difference between discourses of the prosaic in contrast with the poetic and phenomenological; the difference between metanarratives and narratives; differences between faceless others and the faces of others [25]. STEM education in China, reconceptualized as the lived, could then attend to the tension with the planned, listening to the stories of each particular student, embracing the poetic, phenomenological and hermeneutic dimensions of STEM education, which are often neglected not only at the policy level but also in classrooms.

Since the introduction of STEM to China in 2007, its connotation has been enriched and has gradually evolved into STEAM education [9]. Unsatisfactorily, though, despite of the integrative " $\mathrm{A}$ " to STEM, it still suffers a ubiquitous purpose, with impoverished instrumental languages of "enhancing students' creativity", "problem solving skills", and "creativity as a learning outcome" [30] (p. 31). Competency discourses are still present, if not dominant, in its conceptualization. A curricular turn to praxis means more than adding 
an A (Arts) to STEM and forms a new integrative concept of STEAM. Re-understanding STEM as the lived, inspired by Aoki's question, "science must be taught as a humanity", radically challenges reduced models of integration and encourages teachers to dwell in the messy and rough ground of lived experience, poetically, with imagination and alertness.

\subsection{STEM as Ethical Enquiry}

STEM education in China, as is evidenced in policies and implementations, is oriented around the development of skills and competency. Bybee describes STEM literacy as "the conceptual understandings and procedural skills and abilities for individuals to address STEM-related personal, social, and global issues" [31] (p. 31). He seems to place emphasis on conceptual knowledge and procedural skills, and their instrumental purposes, largely neglecting ethical dimensions. Herschbach notes that STEM education lacks curriculum conceptualization, yet he also fails to attend to the ethical dimension of knowledge in his critique. Herschbach's emphasis is still securely anchored to its epistemological concerns of "the formal and applicative uses of knowledge" [5] (p. 96). He categorizes knowledge into theoretical, practical/applied and integrated knowledge, which seems to implicitly further the dichotomized theory and divisive practice, giving the cold shoulder to the ethical and the political. STEM education in China, re-understood as praxis, recovers a conversation about its ethical concerns. Regelski suggests praxis "involves judgments that are both rational and ethical and that bring about 'good' or 'right results' for others or one's own life" [32] (p. 28).

Attempts to link STEM education with values, though few, are detectable [4]. Having observed that value formation tends to be confined to religion or ethics classrooms, SiemensStiftug suggests that value formation in STEM subjects is essential. He encourages STEM lessons to "encourage contemplation, critical reflection and practical application of science and technology in the context of a society" [4]. With a sense of urgency, axiological concerns need to be emphasized, with no spared efforts in STEM education in China, considering not only the impact research has on society, our planet and the human survival, but also how it lies at the core of the STEM education landscape to cultivate caring and cosmopolitan citizenship.

An ethical enquirer in STEM is not someone "who believes he excels others in ingenuity, inventiveness or what not and looks for means to exhibit it. His starting point is anything or situation through which he can exhibit his skill" [18] (p. 22). Rather, it is weaved around the difficult enquiries into the reverberating curriculum question advanced by Herbert Spencer in 1860 and articulated by Pinar on many occasions: "What knowledge is of most worth?". Spencer, in the late 19th century, insisted that the only purpose of education was to prepare for complete living [24]. STEM educators are constantly demanded to make ethical judgements based on creative and spontaneous encounters with others, and take informed and good actions. Students and teachers in STEM classrooms would discuss questions pertaining to values in the form of dilemmas [33], challenging social practices and taken-for-granted norms and raising ethical concerns of transplantation and cloning, the urban food question as a civic movement with a social justice lens, and finally transforming the dualism of man and nature towards a more sustainable future. Unfortunately, as Pinar observes and decries,

[There are] ... decontextualized puzzles preparing for employment in jobs without meaning, a casualty of capitalism's compulsion to profit no matter what it takes ... Just do it becomes the anthem of our time: acting now, suspending judgment, and ignoring ethics; only outcomes matter, and outcomes are numbers, only [34] p. 11.

An ethical enquiry requires us to "distance ourselves from our experience and the world wherein it occurs, that we can remember what we undergo, and that we can exercise some choice in affirming those elements we want to emphasize (and in de-emphasizing those elements we prefer to ignore)" [35] (p. 113). Only by leaving could we return anew. The estrangement entails risks, challenges, and non-coincidences which contribute to one's 
ethical becoming. We will "[end] our narcissistic isolation, ... and can encounter the 'other' [36] (p. 2). I am reminded of Wang's writing about the stranger and her reference to a famous epistemological metaphor of the campfire (associated with Karl Jaspers) [37]. As we "stay close to the light the fire generates so we may see what surrounds us, but we know the larger world exists beyond those shadows the fire casts" [36] (p. 2). As we stay closer to the light of the campfire, we need to have the awareness that there is a much larger world that is seen or could not be seen. Estrangement makes us feel in awe and act with humbleness.

\subsection{STEM as a Historical Text}

When Pinar speaks to the canonical curriculum question about self-knowledge, he confirms ethics as both the content and structure of such knowledge, threaded through history [35]. The ethical dimension of the curriculum field is intimately related to historicity, as well as situatedness. We need to resee STEM education in China as a historical text that keeps informing us and making demands upon us. Interestingly, Grant articulates that "it is only necessary to see how rocked our society was when the Russians got that piece of metal up into the sky before we did. They had beaten us at our own game and the game we consider important. So from our business and military leaders, the cry goes up that we must intensify our history-making activities" [38] (23). The discourse that we must be tougher in our education so that we can produce together history-makers resonates with STEM education's hidden agendas: to make history for the sake of tomorrow, with endless innovations and progresses.

In contrast, the method of currere draws on psychoanalytical tradition in a radical manner, imploring that the notion of curriculum be changed from a noun to a verb, thus becoming historical [39]. The first step in the recursive process is regressive, meaning going back: the past is entered, lived in, but not necessarily succumbed to [39]. Becoming historical is fundamentally different from becoming a "history-maker", as demanded by exploitative activism and modernity. Instead, becoming historical is to be attuned to temporality, to the ineffable alterity upon which everyday experience rests [39] (p. 59). In the Critique of Dialectical Reason, Jean-Paul Sartre posits a view of individual praxis as the basis of human history. I understand it as an invitation for personal narratives as we remember and reactivate history. In our partaking, history provides us with "a sense of identity and collective conscience" [24] (p. 69). STEM education in China is largely characterized as being innovative and forward-looking, unfortunately neglecting its historical heaviness. Pinar understands history "both as a burden (specifically the Soviet influence) and as inspiration (for instance the 1922 Movement), history seems as important a focus ... as do the practices" [40] (p. 227).

Praxis suggests a unification of history and practices-history constantly "haunts" our current undergoing. For China, a country with a long history, its wisdom traditions of Buddhism, Confucianism and Taoism could serve as valuable sources to reconstruct today's STEM education undertaking. Pinar suggests that Buddhism offers a transcending ideal Nirvana, while Confucianism centers on cultivating individual characters in a secular world. Daoism is respectful of nature and of the uniqueness of individuals [40]. The remainder of wisdom traditions could contribute in order to "recover a deeper sense of authentic Chinese identity in a globalizing world" [41] (p. 55).

David Smith sheds further light on what wisdom languages and traditions could do:

The point is to open a space where students can begin to consider the auspices of their lives, and this is best done through a simple remark or point that offers itself for reflection in the context of the students' life situation. Wisdom language points to the much larger and fuller "remainder" of everything that is "said"; it opens out into the authentic silence beyond formal language, to where the actual possibility of finding one's self might be found, paradoxically in the very way that one can be liberated from it [41] (p. 55). 
The Chinese character of a sacred leader (聖人) implies a person who listens and responds to others orally in his historical and worldly indwelling. Ephemeral and original oral dialogues, with attentive listening to one another, seem to echo Pinar's emphasis on orality, as we act over small spaces in a participatory and inclusive manner. An oral society, as Pinar emphasizes, "unites people in face-to-face encounters ... [as well as] orients much of its energy towards not forgetting, towards continuously re-enacting the past in the present" [42] (p. 15). He links the disappearance of an oral society and the lack of attention to history with what technology does to us: "Technology dissolves time, replacing it with an endless immediacy, substituting simulation for embodied experience, ocularcentrism for orality, the cloud occluding what is concealed underneath the Internet of things" [42] (p. ix). In a technological society, what we need is not more advanced and more innovative technology, but deepened understandings and second thoughts about technology per se. As Grant pleads: The first task of thought in our era is to think what technology is [43].

It is "from [the past that] we might discern passages into a future more cosmopolitan than our present proximity permits" [44] (p. 105). To cultivate cosmopolitan and caring citizenship, STEM education has to make its curriculum cosmopolitan which is structured by subjectivity, remaining informed by and connected with historical moments. The educational significance of STEM education in China is dependent upon "its provision of passages between the past and present" [45] (p. 49).

\section{Implications for STEM Teachers}

\subsection{Where will Such a Conversation "Get Us"?}

With the triumphs of modernity, naked utilitarianism and economism, subjects without obvious utility are considered insignificant [45]. STEM is given paramount importance largely due to its strategic roles in producing utility. Pinar righteously cautions: "curriculum became the assembly line by which economically and socially useful citizens would be produced" [24] (p. 95). It is particularly true with the current beliefs about STEM education in China: investing in STEM education for future economic gains and technological advancements. STEM hence risks being reduced to an assembly line, no matter how seemingly innovative it is. We need to restore STEM as a curriculum field rather than a toolset to be mastered as means of social engineering and advancement. It could be re-understood as an opening for educators to inquire into their classes with disciplinary knowledge and interdisciplinary awareness, and to ask what is most worthwhile in the tension between lived and planned curricula.

I could expect that what STEM educators in China are most concerned with is how these re-understandings of STEM through praxis could change their classrooms and practices, and how such a conceptual reconfiguration will transform the practice of STEM in classrooms and on other occasions. On that note, Phelan points to an intriguing comment by David Smith with regards to the potential contribution of curriculum theorizing: "Where will such a conversation 'get us?' in a sense it will not 'get us' anywhere" [23] (p. 217). Pinar is not particularly interested in the "how-to" question as a reconceptualization curriculum theorist. At the same time, he maintains that concepts are not free-floating universals but situated and specific [46]. The reconceptualization movement is significant on the practical level precisely due to its refraining from providing "how-to"s. Intellectual curiosity or wonder emerges and flows with the ebbs of the "how-to"s, no longer subsidiary to the economic gains. In contrast, universities within technological societies tend to privilege those sciences which promise mastery of human and non-human nature [47]. STEM as praxis encourages teachers to listen to the voices of educators and students in their particularity with one another. STEM would be reenergized in the reconceptualization as "a creative intellectual task ... neither used as a basis for prescription or an empirically testable set of principles and relationships, with public dialogue to deliberate about what counts as education" [48] (p. 6).

The renewed praxis approach would keep rejuvenating STEM education. The praxis reconceptualization shifts attention from epistemological questions (i.e., what is the content 
knowledge?) or technical questions (i.e., how could we deliver the knowledge?) to the key curricular question, with its political, historical, ethical dimensions (i.e., what knowledge is of most worth?). This shift brings STEM education back to the rich soil of lived experience, which could be an invaluable and generative source for its sustainable evolvement. STEM educators in China are advised to "surmount the boundaries in which all customary views are confined and to reach a more open territory" [49] (p. 13). STEM is conceived as a pioneer practice to cross the boundaries of disciplines. However, what is worth noticing is that, for one thing, disciplinary investigations could not be overlooked in interdisciplinary attempts. For another, interdisciplinary STEM education could continue to cross more boundaries with boldness and imagination. The possibilities and dimensions of the humanities, including phenomenology, hermeneutics, ethics and historicity, could help recover the complexities in STEM education. STEM education is to be lived rather than merely implemented in a dynamic and dialogic scientific, artistic and poetic manner. It acknowledges the limitations of science and provokes people to ask what we could not measure and master in experimental approaches and, ultimately, to grow new possibilities from its own limitations. STEM as praxis helps "(1) recognizing the unwarranted privileging of the techno-scientific curriculum mindset understood almost totally in terms of objective meanings, (2) calling for a de-privileging such that a clearing can be opened up to allow humanly embodied narratives to dwell contrapuntally with metanarratives" [25] (p. 209).

\subsection{Making Quests for the Good}

Re-understanding STEM education as praxis helps transform the predominant managerial and industrial languages in education. It encourages STEM educators to ask real educational questions embedded in ethical concerns: what counts as good teaching? What counts as educational ideals? What counts as acting well in the world with one another? What is the ethical engagement with human and non-human beings? Ethical knowledge needs to become the root and the compass for STEM education in China. STEM education in China is no longer a policy to be implemented but a space to welcome improvisation through spontaneous, ephemeral, transitional, and organic conversations. STEM teaching materials are not to be instruments for prescribed teaching goals, including advanced technologies and skills competency, but are woven together into people's lived experiences while remaining wide awake of [50] phenomena such as climate change, sustainability, and the COVID-19 crisis.

STEM education in China would not be an advanced curriculum design targeted at elite students but could create a civic square where we often neglect the voices of marginalized groups. This might be particularly important in China's rural education, where many students do not even have access to the internet or other technologies and advanced appliances. The voices of those students from economically impoverished families, as well as rural teachers, are not heard in STEM education in China. What does STEM education mean for the students who do not even have access to a computer? Or, rather, what do marginalized students mean for STEM education? To respond to those difficult questions, it might be helpful to deconstruct STEM education by continuing to ask who decides what. STEM education is encouraged to shift from metanarrative to more personal narratives, from the policy level to the nuanced, messy and unpredictable everyday life of real people, attending to their real concerns and sufferings. The deconstruction process of STEM education does not mean to destruct. Rather, it could be understood as an attempt to reconstruct STEM education in China in renewed discourses. It is fair to say what really legitimizes STEM educators is not their expertness in performing tasks of delivering curriculum content and curriculum development, but, rather, a heartening sensitivity to students and a reflection on what counts as good education in each particular encounter. STEM educators are to cultivate tact and attunement that acknowledge the uniqueness of every teaching situation with each particular person. To raise the content and structure of a STEM curriculum from being mired in a technical view to dwell between two curriculum 
worlds of the planned and the lived is a major challenge, but an urgent move for current curriculum developers [51].

"Science must be taught as a humanity" [25] (p. 199) seems to beckon questioning from the ground up. It seems to me that such a simple question could help deconstruct the structure of STEM education "at all levels into turbulence, opening possibilities of a fresh line of movement for curriculum" [25] (p. 209). STEM educators are not merely professionals with scientific knowledge and applicable models, but human beings who participate in a shared reality and enquire into what counts as good for one another. Ethical considerations such as social justice, democracy, and plurality help determine where STEM should go and what STEM should do.

\subsection{Returning to the Future}

The STEM discourse in China has a futuristic vision defined by its economic promise. However, reconceptualizing STEM as praxis is to realize our future in the past.

Reconstructing the past and recontextualizing concepts imported from abroad, supported by its distinctive and dynamic field of curriculum studies, China's STEM education is advised to enter and reactivate China's own wisdom traditions to reimagine the future. The global pandemic demands us to reflect on the relationship between human beings and the nature in which we reside. More than ever, we have developed awareness and awe about nature. The sense of being out of control during the pandemic is an ironic footnote to omnipotent modernity. Respect for nature has long been advocated and expressed by Daoist tradition for thousands of years; Confucius held the importance of character cultivation as the purpose of education; Nirvana in Buddhism suggests the pathway to freedom is the rebirth after having been burned to ashes. By linking these ancient voices to STEM education, we might detect what is missing from present economic and technological discourses-what counts as good? What is an educational question? What is knowledge of most worth? Ancient wisdom could shed light on a renewal of conversations. STEM education in China would rejuvenate itself in history. It needs to have the courage to criticize, disrupt and eventually grow something new out of the ashes. STEM educators are encouraged to "become historical, which means to extricate themselves from the flat-lined present ... Living in the past through the wisdom traditions ... would no longer be certification of irrelevance but transcendence. Being 'out-of-date' could become an aspiration, not a lamented sign of aging" [35] (p. 233).

\section{Implications on the STEM International Landscape and Possible Limitations}

It is observed, not exclusively in China, that STEM education around the globe in public debates and policies centers on arguments for improving academic proficiency and workforce readiness [52]. The tendency to monitor, compare, and strategize has been detected in data-driven international comparisons of performance in STEM education. Most countries actively invest in strategies to boost STEM participation, student achievement and high-end STEM outcomes, drawing on data-based approaches [53]. Industrial discourses largely contribute to STEM education policies in China. Compared with China's STEM policy around enhancing industry research, development and innovation, some Englishspeaking countries are characterized by configuring policy to address insufficient labor market demands for STEM occupations, while some Western European countries adopt STEM policies focused on school-based pedagogy, curricula and testing [53]. Despite the availability of comparative data and their different policy approaches, "policy makers and professionals in education and science rarely have access to such a nuanced cultural understanding — or rather, partly because of the standardized and context-free nature of the comparative data, a nuanced understanding is elusive" [53] (p. 27).

Hence, this reconceptualization attempt is not merely meaningful to China's context. It bears significance to the international landscape of STEM education. Homogenizing discourses around STEM around the globe will not eliminate new possibilities. Das and Adams call for STEM education to be centered on "lives and geographies of learners, 
their local knowledges, and place experience and accentuate critical, decolonizing, and desettling frameworks to provide learners and educators tools for critical civic participation in STEM" [54] (p. 291). STEM education is international, though always nuanced within historical and national contexts [53].

Possible limitations and new directions are simultaneously embedded in this reconceptualization endeavor. On the contrary to Schwab's critique that the reconceptualization was too conceptual [55], praxis, as the central theme of reconceptualization movement, is always connected with and embedded in experiences with multiple theoretical prisms, including the lived, the ethical, and the historical. Of course, discussions about the gendered, racial, and transcending dimensions of STEM education are beyond the scope of this paper. What also needs to be noted is that the reconceptualization of STEM education as praxis is not easy to translate into policies and classroom practices, especially when taking the differences among primary, secondary and tertiary systems into account. This could be a topic worth of further investigations. What is worth noting is that the difficulty of translation might be a creative space for us educators to linger between the lived and the planned curriculum, and continue to complicate the conversations.

\section{Conclusions}

As policymakers and practitioners are busy pursuing novel ways and pedagogical solutions for STEM education in China, aiming to transform the manufacturing intensive economy into innovative knowledge economy, I propose a re-understanding of STEM education in an "out of joint" way, particularly in dialogue with the humanities.

I recall what Hui Neng tells us as early as the 7th century C.E., "to seek enlightenment by separating from this world is as absurd as to search for a rabbit's horn" [41] (p. 45). If teaching is going to be good work (instead of being a successful job within the well-defined regime), STEM educators need to live in the world more attentively and imaginatively, more than the integration of subjects. It is, rather, a collage of disciplines, improvised jointly by teachers and students, which enables STEM to sustain its own evolution in a continuous tension among disciplines, between practice and theory. The sustainability of STEM education relies on its embeddedness in lived experience, with multidimensional conceptual imaginations. According to Cebrián and Junyent, systems thinking has been widely acknowledged as a fundamental element of sustainability: "the ability to see the interconnections between different dimensions (environmental, development, social, economic, cultural) and the complexity of systems and situations can contribute to the effective problem-solving of sustainability issues" [56] (p. 2770). Understanding STEM as praxis is such an attempt to weave together the multiplicity, interconnectedness and complexity of the lived, the historical and the ethical.

With a curriculum turn, STEM education in China is reconceptualized as praxis, which is focused on reflection and action with phenomenological, hermeneutical, ethical and historical concerns. The transformation will generate "an intensified subjective engagement with the world" [57] (p. 178) in the lived experiences of STEM educators and students. Dwelling in the tension between lived curriculum and planned curriculum, educators could notice each of their particular students, not only the talented but also the marginalized students; not only implementing STEM as a means to an end but also improvising STEM as a dialogic space to generate new meanings.

China's STEM education needs to be anchored in the discussion of values and formations. The knowledge of most worth is self-knowledge, which is an ancient educational injunction implying self-reflection. The reflective process is enabled by structural noncoincidence: being attached to and detached from lived experiences at the same time, so that we can be wide-awake. More importantly, self-knowledge is "no simple matter of paying attention to what happens-although it depends on that-and it requires retrieving what happened already and remains only as residue, and sometimes not readily accessible. This ongoing sense of mystery in fact impels self-study and haunts the formation of the subject" [34] (p. 8). STEM educators in China are advised to refocus their attention from 
policies of, and approaches towards, economic and technological ends to a space pregnant with layers of self-knowledge, to participate in STEM education as lived autobiographically, to challenge prevalent experimental and technical discourses about STEM education, and to embrace the uncertainties and nuances from their own locations or stances in the world.

Indeed, as Pinar references Alfred North Whitehead and proposes the more we know of Chinese art, literature, and of its philosophy of life, the more we appreciate the heights to which that civilization attained [40]. Instead of importing the models of STEM education practices from the West, China's STEM educators and policymakers are encouraged to engage with their own wisdom traditions, to have vertical (e.g., historical) and horizontal (e.g., internationalization) engagement with alterity from inside and outside borders. By reconstructing the past and recontextualizing concepts from abroad, supported by its distinctive and dynamic field of curriculum studies [40], China could reconstruct and sustain STEM education with its curriculum turn.

Funding: This research received no external funding.

Institutional Review Board Statement: Not applicable.

Informed Consent Statement: Not applicable.

Data Availability Statement: Not applicable.

Conflicts of Interest: The author declares no conflict of interests.

\section{References}

1. Ministry of Education of People's Republic of China. China's STEM Education White Paper. Available online: http://www.moe. gov.cn/s78/A16/s5886/s7822/201801/t20180111_324362.html (accessed on 21 January 2021).

2. Kelley, T.R.; Knowles, J.G. A Conceptual Framework for STEM Education. Int. J. STEM Educ. 2016, 3, 1-11. [CrossRef]

3. Gao, Y. An emerging giant of science: Achievements and challenges of STEM education in China. In The Age of Stem: Educational Policy and Practice across the World in Science, Technology, Engineering and Mathematics; Freeman, B., Marginson, S., Tytler, R., Eds.; Routledge: New York, NY, USA, 2017; pp. 47-66.

4. Siemens-Stiftung. STEM and Values: Creating Values in Science and Technology Education. n.d. Siemens-Stiftung. STEM and Values: Creating Values in Science and Technology Education. Available online: https://www.siemens-stiftung.org/en/foundation/ education/stem-and-values / (accessed on 8 March 2021).

5. Herschbach, D.R. The STEM Initiative: Constraints and Challenges. JSTE 2011, 48. [CrossRef]

6. Yuan, Z.Q. An Exploratory Study on Educating Innovative STEM Teachers; Feng Huang Press: Jiang Su, China, 2019.

7. China's STEM Education in Action: Observations, Initiatives and Reflections. Available online: https://edtechchina.medium. com/chinas-stem-education-in-action-observations-initiatives-and-reflections-a20d6cd43a0c (accessed on 2 March 2021).

8. Herscovitz, O.; Kaberman, Z.; Saar, L.; Dori, Y.J. The role of self-monitoring in learning chemistry. In Metacognition in Science Education; Zohar, A., Dori, Y.J., Eds.; Contemporary Trends and Issues in Science Education; Springer: Dordrecht, The Netherlands, 2012; Volume 40, pp. 165-197. ISBN 978-94-007-2131-9.

9. Wang, X.; Xu, W.; Guo, L. The Status Quo and Ways of STEAM Education Promoting China's Future Social Sustainable Development. Sustainability 2018, 10, 4417. [CrossRef]

10. Tyler, R. Basic Principles of Curriculum and Instruction; University of Chicago Press: Chicago, IL, USA, 1950.

11. Pinar, W.F. The Reconceptualisation of Curriculum Studies. J. Curric. Stud. 1978, 10, 205-214. [CrossRef]

12. Ministry of Education of People's Republic of China 13th Fifth Year Plan for Education in the Information Age. Available online: http:/ / www.moe.gov.cn/srcsite/A16/s3342/201606/t20160622_269367.html (accessed on 2 February 2021).

13. Ministry of Education of People's Republic of China. Curriculum Standard for the Compulsory Education in China. 2017. Available online: http:/ / www.moe.gov.cn/srcsite/A26/s8001/201702/W020170215542129302110.pdf (accessed on 2 January 2020).

14. Han, X.; Appelbaum, R.P. China's Science, Technology, Engineering, and Mathematics (STEM) Research Environment: A Snapshot. PLoS ONE 2018, 13, 4. [CrossRef] [PubMed]

15. STEM Teachers Competency Level Standards. Available online: https://wenku.baidu.com/view/1f706e6d59fb770bf78a6529647 d27284b7337d9.html (accessed on 25 January 2021).

16. Ministry of Education of the People's Republic of China "The Plan for Excellent Students Cultivation". Available online: http:/ / www.moe.gov.cn/srcsite/A08/s7056/201810/t20181017_351895.html (accessed on 20 November 2020).

17. Ministry of Education of People's Republic of China Informationization of Education and Internet Security in 2018. Available online: http://www.moe.gov.cn/srcsite/A16/s3342/201803/t20180313_329823.html (accessed on 12 September 2020).

18. Schwab, J.J. What Do Scientist Do? Period. Arch. Online 1960, 5, 1. [CrossRef]

19. Colomer, J.; Serra-Saurina, L.; Cañabate, D.; Serra, T. Evaluating Knowledge and Assessment-Centered Reflective-Based Learning Approaches. Sustainability 2018, 10, 3122. [CrossRef] 
20. Fraser, S.; Earle, W.T.; Fitzallen, N. What Is in an Acronym? Experiencing STEM Education in Australia. In STEM Education: An Emerging Field of Inquiry; Barkatsas, T., Carr, N., Cooper, G., Eds.; Brill Sense: Leiden, The Netherlands; Boston, MA, USA, 2019; pp. 9-30.

21. Van Driel, J.H.; Vossen, T.; Henze, I.; De Vries, M.J. Delivering STEM Education through School-Industry Partnerships: A Focus on Research and Design. In STEM Education: An Emerging Field of Inquiry; Barkatsas, T., Carr, N., Cooper, G., Eds.; Global Education in the 21st Century, Series; Brill Sense: Leiden, The Netherlands; Boston, MA, USA, 2019; ISBN 978-90-04-39140-6.

22. Cunningham, W.; Villaseñor, P. Employer voics, employer demands, and implications for public skills development policy connecting the labor and educatoin sectors. World Bank Res. Obs. 2016, 31, 102-134. [CrossRef]

23. Phelan, A.M. Towards a Complicated Conversation: Teacher Education and the Curriculum Turn. Pedagog. Cult. Soc. 2011, 19, 207-220. [CrossRef]

24. Pinar, W.F.; Reynolds, W.M.; Slattery, P.; Taubman, P.M. Understanding Curriculum; Peter Lang Publishing, Inc.: New York, NY, USA, 2002; ISBN 7-5019-4603-3.

25. Aoki, T.T. Legitimating Lived Curriculum: Toward a Curricular Landscape of Multiplicity (1993). In Curriculum in a Neww Key: The Collected Works of Ted T. Aoki; Pinar, W.F., Irwin, R.L., Eds.; Lawrence Erlbaum Associates, Inc.: Mahwah, NJ, USA, 2004; pp. 199-218.

26. Flyvbjerg, B. Making Social Science Matter: Why Social Inquiry Fails and How It Can Succeed Again; Cambridge University Press: Cambridge, UK, 2001.

27. Phelan, A.M.; Hans, S.; Ying, M. Philosophical Issues in Initial Teacher Education. In Handbook of Canadian Research in Initial Teacher Education; Falkenberg, T., Ed.; Canadian Association for Teacher Education: Ottawa, Canada, 2015; pp. 227-244. ISBN 978-0-9947451-3-2.

28. Greene, M. The Dialectic of Freedom; Teachers College, Columbia University: New York, NY, USA; London, UK, 1988.

29. Greene, M. Teaching for Openings. In Releasing the Imagination: Essays on Education, the Arts and Social Change; Jossey-Bass Publishers: San Francisco, CA, USA, 1995; pp. 109-121.

30. Perignat, E.; Katz-Buonincontro, J. STEAM in Practice and Research: An Integrative Literature Review. Think. Ski. Creat. 2019, 31, 31-43. [CrossRef]

31. Bybee, B.R.W. Advancing STEM Education: A 2020 Vision. Technol. Eng. Teacer. 2010, 70, 30-36.

32. Regelski, T.A. The Aristotelian Bases of Praxis for Music and Music Education as Praxis. Philos. Music Educ. Rev. $2011,6,22-59$.

33. Jiang, C.; Seah, W.T.; Barkatsas, T.; Ieong, S.S.L.; Cheong, I.K. Values in STEM Education: Investigating Macau Secondary Students' Valuing in Mathematics Learning. In STEM Education: An Emerging Field of Inquiry; Barkatsas, T., Carr, N., Cooper, G., Eds.; Brill Sense: Leiden, The Netherlands; Boston, MA, USA, 2019; pp. 132-154.

34. Pinar, W.F. The Character of Curriculum Studies: Bildung, Currere, and the Recurring Question of the Subject; Palgrave Macmillan: New York, NY, USA, 2011.

35. Pinar, W.F. Educational Experience as Lived: Knowledge, History, Alterity: The Selected Works of William F. Pinar, 1st ed.; Routledge: New York, NY, USA; London, UK, 2015; ISBN 978-1-315-75259-4.

36. Pinar, W.F. Exile and Estrangement in the Internationalization of Curriculum Studies. J. Am. Assoc. Adv. Curric. Stud. 2006, 2, $1-18$.

37. Wang, H. The Call from the Stranger on a Journey Home: Curriculum in a Third Space; Peter Lang: New York, NY, USA, 2004.

38. Grant, G. Philosophy in the Mass Age; Copp Clark Publishing: Toronto, ON, Canada, 1959.

39. Pinar, W.F. The Method of Currere; ERIC: Washington, DC, USA, 1975.

40. Pinar, W.F. Curriculum Studies in China: Reform, Culture, History. In Curriculum Studies in China: Intellectual Histories, Present Circumstances.; Pinar, W.F., Ed.; Palgrave Macmillan: New York, NY, USA, 2014.

41. Smith, D.S. Wisdom Responses to Globalization. In International Handbook of Curriculum Research; Pinar, W., Ed.; Routledge: New York, NY, USA, 2013; ISBN 978-0-203-83169-4.

42. William, P.F. Moving Images of Eternity: George Grant's Critique of Time, Teaching, and Technology; University of Ottawa Press: Ottawa, ON, Canada, 2019.

43. Grant, G. English-Speaking Justice; Anansi: Toronto, ON, Canada, 1974.

44. Pinar, W.F. Currere and Cosmopolitanism. In The Character of Curriculum Studies; Palgrave Macmillan: New York, NY, USA, 2011; pp. 105-121.

45. Pinar, W.F. George Grant's Cosmopolitan Critique of Education. Encounters 2013, 14, 49-69. [CrossRef]

46. Pinar, W.F. The Exchange with Janet L. Miller. In Curriculum Studies in China: Intellectual Histories, Present Circumstances; Pinar, W.F., Ed.; Palgrave Macmillan: New York, NY, USA, 2014; pp. 157-222.

47. Grant, G. Technology \& Empire; Anansi: Toronto, ON, Canada, 1969.

48. Macdonald, J.B. Curriculum Theory. In Curriculum Theorizing: The Reconceptualists; Pinar, W.F., Ed.; McCutchan: Berkeley, CA, USA, 1975.

49. Heidegger, M. What Is Called Thinking? Harper \& Row: New York, NY, USA, 1968.

50. Greene, M. Landscapes of Learning; Teachers College Press: New York, NY, USA, 1978.

51. Aoki, T.T. Teaching as indwelling between two curriculum worlds. In Inspiriting Curriculum and Pedagogy: Talks to Teachers; Aoki, T.T., Ed.; University of Alberta: Edmonton, AL, Canada, 1991; pp. 7-10. 
52. Kayumova, S. Engaging with Complexities and Imaging possibilities across the boundaries of STEM. In Critical, Transdisciplinary and Embodied Approaches in STEM Education; Senputa, P., Shanahan, M.-C., Kim, B., Eds.; Advances in STEM Education; Springer: Cham, Switzerland, 2019; pp. 251-258.

53. Marginson, S. What international comparisons can tell us. In The Age of STEM: Educational Policy and Practice across the Wrold in Scinece, Technology, Engineering and Mathematics; Freeman, B., Marginson, S., Tytler, R., Eds.; Routledge: New York, NY, USA, 2015

54. Das, A.; Adams, J. Critical Transdisciplinary STEM: A Critical Numeracy Approach to STEM Praxis by Urban Environments and Education Research Coven. In Critical, Transdisciplinary and Embodied Approaches in STEM Education; Senputa, P., Shanahan, M.-C., Kim, B., Eds.; Advances in STEM Education; Springer: Cham, Switzerland, 2019; pp. 291-306.

55. Schwab, J.J. The Practical: A Language for Curriculum; National Education Association.: Washington, DC, USA, 1970.

56. Cebrián, G.; Junyent, M. Competencies in Education for Sustainable Development: Exploring the Student Teachers' Views. Sustainability 2015, 7, 2768-2786. [CrossRef]

57. Pinar, W.F. Currere. In Encyclopedia of Curriculum Studies; Kridel, C., Ed.; Sage: Thousand Oaks, CA, USA, 2010 ; pp. 177-178. 